\title{
RURAL LANDSCAPE MULTIFUNCTIONALITY: A GIS BASED APPROACH FOR ASSESSING AREAS CHARACTERISED BY ECOLOGICAL FUNCTIONS
}

\author{
Maurizia Sigura
}

\section{Introduction}

During the last decades, the rationalisation of agricultural practices reduced the diversity of rural landscape and procured the abandonment of agriculture in marginal land. This caused the loss of important habitats for biodiversity conservation which are highly dependent on the continuation of such agricultural activities. Natural resources of rural landscapes are largely managed by agriculture, expecially by multifunctional agriculture. The concept of multifunctional agriculture refers to the idea that agriculture has many functions in addition to producing food and fiber, like environmental protection, landscape preservation, rural employment, food security, etc. [World Trade Organisation 2000]. Agriculture contributes through several of these functions to achieve sustainable development.

The UE Common agricultural policy supports multifunctionality in agriculture by different instruments like the rural development plans [Council Regulation EC 1698/2005, Council decision 2006/144/EC], that provide relevant frameworks (agri-environment and Natura 2000 payments) targeted towards the preservation of habitat and biodiversity. Furthermore, sustainable development needs to obtain this integration at the landscape scale, not only at the farmland scale. This goal is achieved by a rural development planning process based on specific knowledge and supported by dedicated decision support systems.

Two important concepts can be used to obtain the sustainability of this planning process: ecological network and High Natural Value Farmland (HNVF) areas. The ecological network is defined as: "a coherent system of natural and/or semi-natural landscape elements that is configured and managed with the objective of maintaining or restoring ecological functions

Paper received 24.03.2010; accepted 28.09.2010

Sigura Maurizia (maurizia.sigura@uniud.it) researcher at the Department of Agricultural and Environmental Sciences, University of Udine, Via delle Scienze, 208, località Rizzi, Udine, Italy. as a means to conserve biodiversity while also providing appropriate opportunities for the sustainable use of natural resources" [Bennett 2004].

HNVF are "agricultural areas covered with seminatural vegetation with high levels of biodiversity (meadows and pastures, hay-meadows, or mosaics of extensive agriculture) which constitute a natural habitat and a shelter for plant and animal species allowing them to coexist with the surrounding farming activity" [Andersen 2003].

The ecological network bases its structure in the cultivated areas, and can be managed by a suite of agri-environmental measures and by the restoration of the landscape heterogeneity formed by farming and forestry activities [Boitani 2007].

The involvement of agricultural areas in the ecological network framework is not new and many examples are found in Europe. In the Netherlands the National Ecological Network also comprises high nature value agricultural areas, subsidized to be managed under agro-environmental schemes [Biemans 2008]. The Czech Republic Territorial System of Landscape Ecological Stability supports multi-functional land use, through a network of ecologically important landscape segments based on functional spatial criteria aimed at the preservation of biodiversity and nature conservation [Kubeš 1996]. Other examples are the ecological network of the Walloon region (Belgium), the Estonian Network of Ecological Compensating Areas and the Danish Ecological Networks/Naturverbindsele [Jongman 1995].

The relations between biodiversity and agricultural activities (and between concepts of HNVF and ecological network) are very important. In fact around half the EU's land is farmed, and agricultural areas are characterized by specific biodiversity, which results from farm management.

Biodiversity is a complex entity and occours at different scales. Peeters [2004] proposed three aspects of biodiversity in rural landscape: the agricultural biodiversity (the variety of life used for the farming production, like cultivated species), the para-agricultural biodiversity (wild species and spontaneous communities with positive or negative effects on the production sys- 
tem) and the extra-agricultural biodiversity, represented by wild species and habitats more or less associated with the system, but not involved in production.

This perspective leads to a question: which parameters and which tools are needed to identify the elements of the ecological network in the rural landscape?

The aim of this study was to develop a GIS methodology useful in identifying the strategic places for the ecological network in a rural landscape, where human activities are involved. The survey of the ecological network was done in order to develop an instrument as a decision support system for local planning in rural areas and for the implementation of rural development plans.

\section{Materials and methods}

For the identification of the ecological network structure in the rural landscape, we assume that landuse type and human activities interact with the species-specific use of landscape pattern and with the movement of species.

GIS was used in two different analysis: the landscape model, in order to identify suitable areas for species, and the connectivity model, in order to define potential corridors between suitable areas.

According to other authors we used a model rule for the localisation of suitable patches for a target species [Vuilleumier 2002; Shadt 2002; Nilolakaky 2005]. A cost distance analysis was used to model the connectivity, expressing the ability of species to move between different elements of the landscape.

One of the most important phases in developing a GIS model is acquiring data suitable for the analyses. The approach used require fauna species data and landscape structure data. The statistical analyses were performed by Statistica StatSoft and GIS elaborations were done by ArcGis Esri.

\subsection{Study area}

The study area (Fig. 1) is part of the Friuli Venezia Giulia plain (North-eastern Italy), and covers 1830 $\mathrm{km}^{2}$ (70 municipalities). The lithology is characterised by alluvial deposits formed by calcareous material, rivers and canals which make up the surface waters. There are different vegetation types such as riparian vegetation, woods, wetland, grasslands and hedges [Del Favero 1998].

In the last years agriculture in Friuli Venezia Giulia has decreased in economic importance but continues to be a basic component of the socio economic system mainly as a link between human activity and the environment. In cultivated areas the crops pattern is characterized by cereals (monoculture of maize is widely adopted), but also by vineyards, orchards, forage crops and poplar plantations. In the area, reclamation and land consolidation works (operations carried out along with the introduction of irrigation and agricultural land settlement) had a large impact on rural landscape simplification and on the intensification of agriculture [Bonfanti 1999].

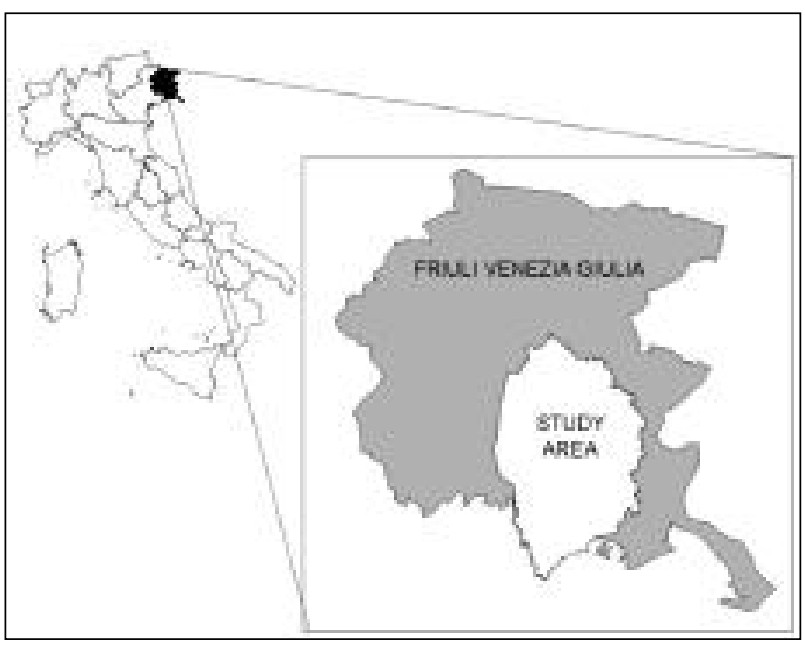

Fig. 1 - Study area.

\subsection{Choice of species}

Habitat preferences for species depend on different factors such as the abundance of food resources, presence of reproductive places, cover, etc. The selection of a focal species may be targeted on species with specific and well-known demands in habitat typology, distribution and that satisfy an array of species with similar needs [Bani 2002; Bruinderink 2003; Boitani 2007]. We assumed a species specific approach based on the use of habitat for the species roe deer (Capreolus capreolus). The roe deer was considered a focal species because it is affected by the landscape structure. In fact it is a forest-dwelling ungulate whose home range size is related to woodland fragmentation [Saïd 2005; Lamberti 2006] and to landscape variables like edge density [Saïd 2005]. In fragmented woodland areas roe deer dispersal is strongly linked to wooded structures, so the population is influenced by the connectivity of the landscape [Coulon 2004].

The consistency data of the species (n. individuals/100 ha) has been obtained from the hunted fauna census developed by the Friuli Venezia Giulia Region.

\subsection{Landscape Model}

Landscape pattern data were obtained by the "land use/cover map 2000" (1:25.000) created within the MOLAND project (Monitoring Land Use/Cover Dynamics, Friuli Venezia Giulia region). The legend used corresponds to the Corine Land Cover III level and is developed in 45 classes of soil coverage (28 in the study area). Additional data has been acquired for roads, artificial channels required for irrigation [Regional Cartography CTRN 1:25.000] and for the dis- 
tribution of broad-leaved woods in plain areas [Regional Forest Inventory Wood Plain, Friuli Venezia Giulia Region, 1999].

Variables of landscape composition (\% of the 28 land use classes) were calculated, as well as the woods characteristics (mean area patch, mean perimeter, mean patch distance, perimeter area mean ratio, patch density and perimeter density). The most important landscape variables and wood characteristics for presence of species (roe deer) were calculated by the Stepwise forward regression [Statistica, StatSoft].

The landscape model was based both on the results of statistical analysis and on rules related to the specific focal species habitat use (tab.1), derived from a number of studies developed in North and central Europe.

The "field roe deer" lives in the open landscapes characterised by less woodland cover and by a higher presence of crops, such as in the study area that has been analysed. This is not a different ecotype in contrast between the classic forest roe deer, but rather a point on a gradient of intra-specific behavioural flexibility, which has been environmentally determined [Andersen 1998]. Populations of field roe deer live in open landscapes for much of the year and the key factor that remains constant in all populations is their strong attachment to woodlands [Aulak 1990; Hewison 1998; Maulanc 1987; Zeyda 1985; Saïd 2005].

Core areas were recognised by the most correlated landscape variables (land uses and woods characteristics) with presence of species which resulted form the statistical analyses. Field studies showed that during the winter season grazing roe deer were found in the 0-200 $\mathrm{m}$ belt from the forest edge [Aulak 1990]. Therefore, contiguous wood patches and wood patches separated less than $200 \mathrm{~m}$ were considered continuous. Roe deer can be considered an ecotone species that use forest and adjacent fields. These animals temporarily leave the forest and move into fields and use agrocenoses vegetation as an additional source of food [Simonetta 2000]. Studies found that the roe deer penetration zone in fields extended up to about $500 \mathrm{~m}$ from the forest edge [Aulak 1990]. This distance was used to define the intensive used area as the buffer zone that shields the core areas.
Amongst the factors which affect species distribution, human disturbance is considered the most important one [Simonetta 2000]. So, the urban areas, the road infrastructures (railway, motorway and roads with a lot of traffic) and the artificial channels have been considered to be barriers and have been substracted from the suitable habitat areas.

The minimum dimension of the areas considered to be suitable has been established equal to at least a vital space (home range). The use of the territory by the roe deer adapted to the various agricultural covered spaces depends on the abundance of the food resources, on the density of the animals, on the season, on the age and from the amount of forest coverage [Hewison 1998]. In order to quantify the home range amplitude we have referred to the winter season vital spaces. We assumed that the home range was equal to 100 ha for forest coverage of 14\% [Maublanc, 1987] and 200 ha for forest coverage which is equal to $6 \%$ [Zeida 1985].

\subsection{Connectivity model}

In order to assess connectivity between the suitable areas defined by the landscape model a cost distance analysis was done [Adriaensen 2003] and a landscape permeability value was assigned to the different land use types.

This value measures the degree of impedance the land use poses to the species movement (Tab.2) and comes from expert knowledge and literature review [Beier, 2008]. The group of experts was composed of researchers from the University of Udine and technicians of the Wildlife Studies Office of regional administration, all with experience in the monitoring and management of species. For each land use type a list of variables effecting permeability was estimated. The values, ranged between 0 to 10 , were ranked to match species requirements for: mimesis, food resource, covering in reproduction time, flight and dispersal movement. This reflects the need to have many variables to build expert models [Doswald 2007]. In order to trasform the expert knowledge into a numerical form the landscape resistance was calculated as a complement to the maximum value obtained for the

\begin{tabular}{|l|l|}
\hline Rules & \multicolumn{1}{|c|}{ Rules explanation } \\
\hline Rule 1 & Core areas were formed by the most correlated landscape variables with presence of species \\
\hline Rule 2 & Contiguous wood patches and wood patches less than $200 \mathrm{~m}$ were considered therefore to be continuous \\
\hline Rule 3 & $\begin{array}{l}\text { The distance used to define the intensive used area (the buffer zone that shields the core areas) is } 500 \mathrm{~m} \text { from } \\
\text { the forest edge }\end{array}$ \\
\hline rule 4 & $\begin{array}{l}\text { The urban areas, the rosd inftastructurcs (railway, motorway and foads with a lot of traffic) and the artificial } \\
\text { channels have been considered as barriers and have been subtracted from the suritable habitat areas }\end{array}$ \\
\hline Rule 5 & $\begin{array}{l}\text { The minimum dimension of the aress coesidered to be saitable has been established equal to, at least, a vital } \\
\text { space (home range) }\end{array}$ \\
\hline
\end{tabular}


sum of the five functions ( $\max$ value 50 ), successively rescaled in a $0-1000$ scale by formula 1

$$
\begin{gathered}
(x-\min / \max -\min )_{*} 1.000 \\
\min =1, \max =50
\end{gathered}
$$

A cost-weighted distance analysis [Arc GIS, Esri] was performed. It was based on a model resistance across a surface cost and returns a least cost travel path from sources to sinks. The land use map was reclassed to a Cost surface layer, which shows the pattern as a mosaic of 18 different types of landscape resistances ( 0 value for areas with no resistance), where building areas, highways (except if viaduct), artificial canals, quarries and dumps are barriers (highest resistance value). Roads were spatially represented by a buffer distance increasing on the base of the stress induced by traffic: highway, $40 \mathrm{~m}$, main road and railway $20 \mathrm{~m}$, secondary road $10 \mathrm{~m}$.

By the GIS we calculated the last cumulative cost from each cell to the nearest and cheapest source [Johnston and McCoy, 2001]. The sources were patches of suitable habitats situated in the North and in the North-East of the study area where source populations were found. The Cost path function was

used to determine the least cost corridors between all the suitable habitat areas.

\section{Results and discussion}

\subsection{Landscape model}

The regression analysis (Stepwise forward regression) showed that the more important variables for target species were $\%$ of broad-leaved woods areas, $\%$ of vineyards and patch density of woods, $(\mathrm{R} 2=0.628$, $\mathrm{F}(3.56)=31.579, \mathrm{p}<<0.001)$.

The rules landscape model allows to obtain the

\begin{tabular}{|c|c|c|c|c|c|c|c|c|}
\hline Land wse & Mimesis & $\begin{array}{l}\text { Food } \\
\text { resauree }\end{array}$ & $\begin{array}{l}\text { Coweriag in } \\
\text { reproduction time }\end{array}$ & $\begin{array}{l}\text { Flight } \\
\text { menement }\end{array}$ & $\begin{array}{l}\text { Dispersal } \\
\text { movement }\end{array}$ & $\begin{array}{l}\text { Landseape } \\
\text { permeataility }\end{array}$ & $\begin{array}{l}\text { Landscape } \\
\text { resistance } \\
\text { (xale 0-sin }\end{array}$ & $\begin{array}{l}\text { Landscaps } \\
\text { resistance } \\
\text { (sale o- } \\
\text { tiog) }\end{array}$ \\
\hline Bread-keaved forests & 10 & 9 & 10 & 10 & 10 & 49 & 1 & 0 \\
\hline Comiferuus forests & 7 & 7 & 8 & 10 & 10 & 42 & 8 & 143 \\
\hline $\begin{array}{l}\text { Transitional } \\
\text { weodland/shrub }\end{array}$ & 9 & 10 & 9 & 10 & 10 & 48 & 2 & 20 \\
\hline Nateral grassland & 6 & 7 & 4 & 9 & 8 & 34 & 16 & 306 \\
\hline $\begin{array}{l}\text { Sparsely vegetated } \\
\text { areas }\end{array}$ & 1 & I & 0 & 7 & 8 & 17 & 33 & 653 \\
\hline Salt manhes & 2 & 4 & 0 & 4 & 6 & 16 & 34 & 673 \\
\hline Inland marshes & 3 & 5 & 1 & 6 & 7 & 22 & 28 & 551 \\
\hline Beaches, dunes, sands & 0 & 0 & 0 & 4 & 4 & 8 & 42 & 837 \\
\hline $\begin{array}{l}\text { Agriculture with } \\
\text { significant vegetation } \\
\text { natural areas }\end{array}$ & 6 & 8 & 6 & 9 & 7 & 36 & 14 & 265 \\
\hline $\begin{array}{l}\text { Nen irrigated arable } \\
\text { land }\end{array}$ & 3 & 6 & 5 & 8 & 5 & 27 & 23 & 449 \\
\hline Fruit trees & 4 & 8 & 2 & 8 & 8 & 30 & 20 & 388 \\
\hline Vineyards & 4 & 9 & 2 & 8 & 8 & 31 & 19 & 367 \\
\hline Rivers & 0 & 0 & 0 & 2 & 3 & 5 & 45 & 898 \\
\hline Artificial eanals & 0 & 0 & 0 & 0 & D & 0 & 50 & 1000 \\
\hline $\begin{array}{l}\text { Continuous wrban } \\
\text { fabric }\end{array}$ & 0 & 0 & 0 & 0 & D & 0 & 50 & 1000 \\
\hline $\begin{array}{l}\text { Discestianous urban } \\
\text { fabric }\end{array}$ & 2 & 3 & 0 & 3 & 0 & 8 & 42 & 837 \\
\hline Greven urban arvas & 3 & 3 & 1 & 4 & 4 & 15 & 35 & 694 \\
\hline $\begin{array}{l}\text { Sport and lésure } \\
\text { facilities }\end{array}$ & 3 & 3 & 1 & 4 & 4 & 15 & 35 & 694 \\
\hline Quarry and dump sites & 0 & 0 & 0 & 0 & 0 & 0 & 50 & 1000 \\
\hline $\begin{array}{l}\text { Peailuays and } \\
\text { associated bed }\end{array}$ & 0 & 0 & 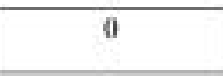 & 3 & 3 & 6 & 44 & 878 \\
\hline Secandary roads & 0 & 0 & 0 & 3 & 3 & 6 & 44 & 878 \\
\hline Main roads & 0 & 0 & 0 & 1 & 2 & 3 & 47 & 939 \\
\hline Highway & 0 & 0 & 0 & 0 & 1 & 1 & 49 & 1000 \\
\hline Industrial areas & 0 & 1 & 0 & 1 & 0 & 2 & 48 & 959 \\
\hline
\end{tabular}
model of the suitable areas for the species, shown in

TABLE 2 - Permeability values and landscape resistance values assigned to land use types. Permeability values were ranked to match requirements for: mimesis, food resources, covering in reproduction time, flight and dispersal movements. 
the Map of Suitable Habitat (Fig. 2).

The suitable areas are concentrated in the North, North-East and in the South of the study area, whereas the central part is much more inhospitable and characterized by three unique and suitable strips, which correspond to rivers. In a dimensional perspective the patches occupy 9307 ha and are divided into zones whose ampleness goes from a minimum of 103 ha to a maximum of 5400 ha. Less than $50 \%$ of the areas exceed 300 ha and only $6 \%$ of them extended more than 1000 ha. The land use is dominated by agriculture. On average $75 \%$ (min $19 \%$, max 96\%) of the suitable area is occupied by agriculture, followed by $16 \%$ of woods $(\min 2 \%, \max 56 \%), 4 \%(\min 0 \%, \max 50 \%)$ of sparsely vegetated areas and natural grassland, 3\% (min 0\%, $\max 34 \%$ ) of transitional woodland/shrub and $2 \%$ (min $0 \%, \max 39 \%)$ of vineyards.

The Map of Suitable Habitat shows the portions of land mainly characterised by ecological functions. The question now is: do these areas fit in areas of high natural value and are they protected by environmental conservation programs?

This aspect was analysed with respect to the protected areas by regional law ( $\mathrm{Lr} \mathrm{n} .46,1992)$ and by the UE Directive 92/43/CEE (Nature 2000). The overlay between the Map of Suitable Habitat and the protected areas points out that $70 \%$ of the identified areas contains inside portions or entire protected areas. At least $76 \%$ of suitable areas adjoin a protected area (Fig. 3). Therefore, the model focused on a species, but it is representative of the natural values of the rural area studied.

\subsection{Connectivity model}

The connectivity model (Fig. 4) shows the most favourable ways of connection between the suitable patches. 115 corridors were identified, for a total of $96 \mathrm{~km}$ full-run. The average length is $632 \mathrm{~m}(\max 9$ $\mathrm{km}$, min $10 \mathrm{~m}$ ). The model showed the isolation and the absence of connections between the North and the South aglomerates of suitable areas.

The landscape elements involved in the routes were: non-irrigated arable land $(50 \%)$, transitional woodland/shrub areas (19\%), woods (16\%), discontinuous urban fabric $(1.6 \%)$, vineyards $(2 \%)$, complex cultivation patterns $(3 \%)$.

The connectivity model allowed us to identify the corridors, but did not give information about their quality.

So, the analysis of the role of landscape elements, as negative elements or barriers, was carried out by the assignment of negative scores (Tab. 3), in agreement with other studies on the connectivity between areas of suitable habitat [Shadt et al, 2002]. The goal is to classify the paths based on the following criteria:

- length of the route in unsuitable land use (e.g. urban areas, industry areas, open fields, meadows);

- crossed roads, (n. of cross of roads characterized by different levels of traffic).

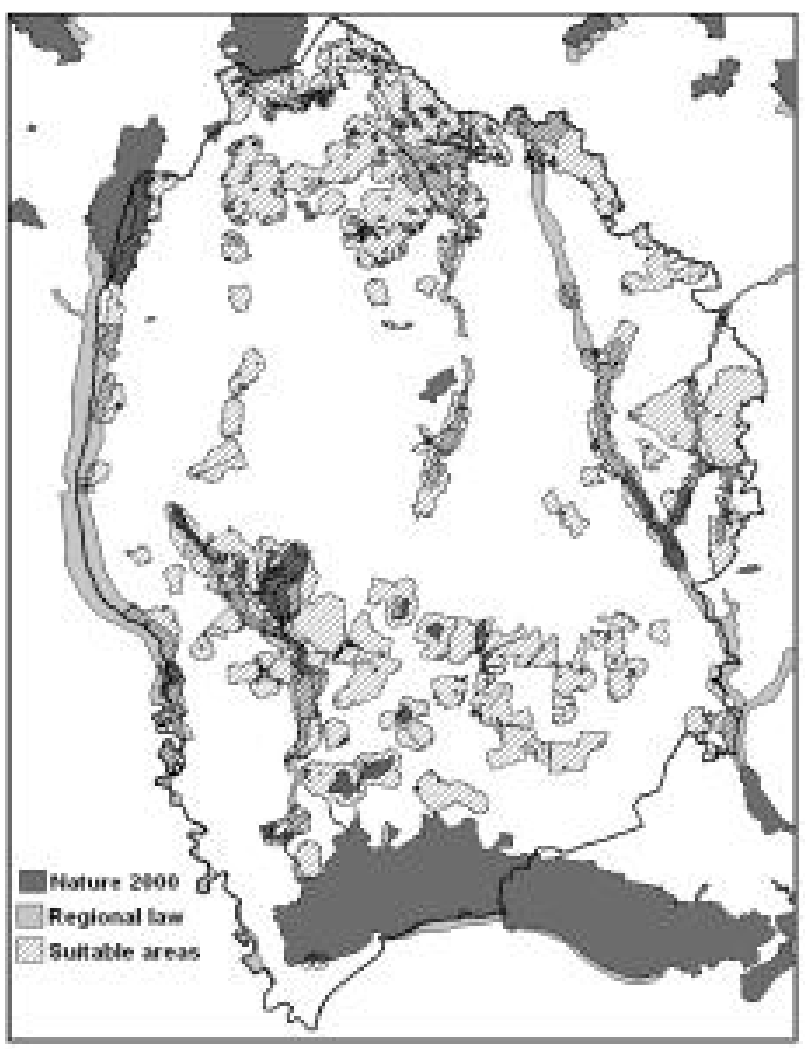

Fig. 3 - Suitable habitats fitting in areas of high natural value.

Fig. 2 - Map of Suitable Habitat and main idrography. 
The values obtained for the quality of corridors, reported in Table 4, point out that the high or very high quality $(62 \%)$ is associated with short corridors. Probably these are the connections between suitable areas in the North and in the South aglomerates of suitable area showed by the landscape model. 33\% of corridors were characterised by a medium or low quality.

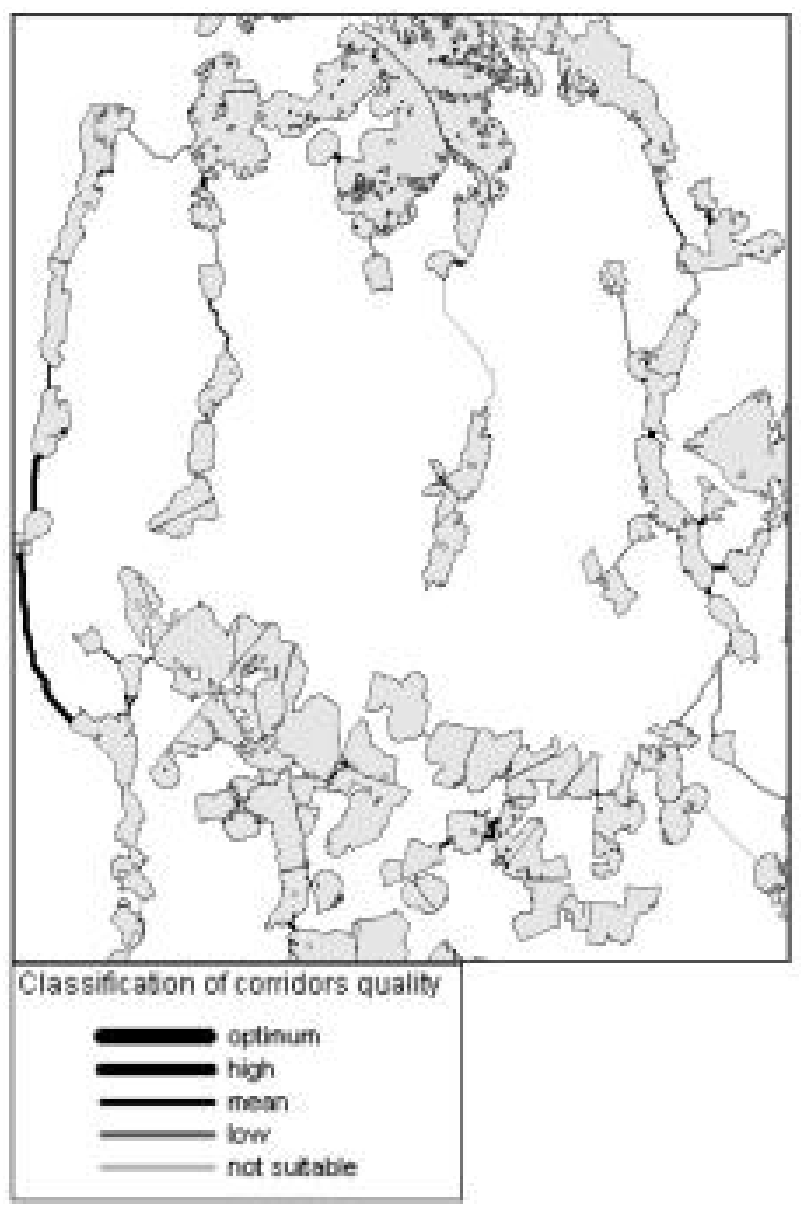

Fig. 4 - Map of Potential corridors and classification.

\begin{tabular}{|l|c|l|}
\hline \multicolumn{1}{|c|}{ Criteria } & Score & \multicolumn{1}{|c|}{ Land uses } \\
\hline length of the path in & -50 & $\begin{array}{l}\text { urban areas, } \\
\text { industrial areas } \\
\text { (score/km) }\end{array}$ \\
\cline { 2 - 3 } $\begin{array}{l}\text { unsuitable land use or } \\
\text { in less suitable landuse }\end{array}$ & -5 & $\begin{array}{l}\text { wetland areas, } \\
\text { pastures, areas } \\
\text { cover by scrubs, } \\
\text { meadows } \\
\text { (score/km) }\end{array}$ \\
\hline crossing barriers & -50 & $\begin{array}{l}\text { main roads } \\
\text { characterized by } \\
\text { a lot of traffic } \\
\text { (score/cross) }\end{array}$ \\
\cline { 2 - 3 } & -20 & $\begin{array}{l}\text { secondary roads } \\
\text { characterized by } \\
\text { less traffic } \\
\text { (score/cross) }\end{array}$ \\
\hline
\end{tabular}

TABLE 3 - Scores and criteria used in the quality evaluation of corridors.

\begin{tabular}{|c|c|c|c|}
\hline Quality & Score & $\begin{array}{c}\text { Corridors } \\
(\mathbf{n} .)\end{array}$ & $\begin{array}{c}\text { Average lengh } \\
(\mathbf{m})\end{array}$ \\
\hline Optimum & 0 & 24 & $\begin{array}{c}268 \\
(\max 2.752, \min 10)\end{array}$ \\
\hline High & 20 & 48 & $\begin{array}{c}128 \\
(\max 1910, \min 10)\end{array}$ \\
\hline Medium & $20-50$ & 16 & $\begin{array}{c}1.508 \\
(\max 9086, \min 13)\end{array}$ \\
\hline Low & $50-100$ & 22 & $\begin{array}{c}1.215 \\
(\max 4.292, \min 11)\end{array}$ \\
\hline $\begin{array}{c}\text { Not } \\
\text { suitable }\end{array}$ & $>100$ & 5 & $\begin{array}{c}4.594 \\
(\max 9.327, \min 595)\end{array}$ \\
\hline
\end{tabular}

TABLE 4 - Classes of quality for corridors.

The results of the landscape and connectivity model indicated that in the rural landscape there were all the ecological network elements: nodes (suitable areas), corridors (linear corridors).

Both suitable areas and corridors are characterized by a great presence of arable land and woodland. A great part of suitable areas are also environmental conservation areas. This can generate conflicts between agricultural production and nature conservation aims. In fact, these areas are characterised by natural values and also by agricultural land uses that should be associated with high biodiversity or species and habitat of European wide interest. So, these rural areas must support both economic and natural functions. This conflict may become an opportunity for farmers.

The UE agriculture policy, by Rural development plans, supports environmental sound agriculture through agri-environment measures. Moreover, the preservation of natural elements and of landscape diversity constitute a prerequisite for other activities in agriculture like eco-tourism or teaching farms.

A possible limit of the method is the representation of the corridors by line. The track should not be understood as the corridor itself, but as the localization of favourable conditions for corridor. The corridor areas should be large portions of land, managed by extensive agriculture in order to facilitate the conservation of natural habitats. The analyses of the quality of the corridors point out critical points for conectivity between suitable areas. In particular, the connection between the North and the South areas is possible only by one corridor of good quality. Many suitable areas, expecially located along the rivers, are linked by corridors of less quality, so probably the isolation is higher than what we can aspect.

The maps which have been obtained can be useful instruments in order to involve policy makers, and other stakeholders, in the decision process on land use planning. In this way, the ecological network model can be a useful instrument in order to give valuable knowledge about environmental functions of rural landscape and to show constraints and possibilities to change the landscape in the boundaries of sustainability. 


\section{Conclusions}

The method proposed is based on several assumptions, but offers a flexible tool, useful to integrate human pressures with natural values in the land use planning process.

The study is restricted to one focal species, but its characteristics imply that the results satisfy an array of species (medium size species) with similar needs.

The used rules model is particularly helpful in absence of quantitative data about species distribution and allows to define the areas where environmental sound agriculture is more important. Anyway, the approach provides a template to incorporate more species and habitat. The two models, based on GIS technology, offer the possibility to add or eliminate types of landscape elements, to change the source for distance analysis and to change the rules on the basis of different target species.

The ecological network was assessed in a rural landscape where human activities are involved and strategic places, characterized by ecological functions, were identified on the basis of environmental parameters and socio economic constraints. The models have showed their capacity to analyse the impact of constraints on the presence of suitable habitats and wildlife movement.

The resulting maps provide useful information and can help decision makers to plan activity at the local or at the landscape scale.

The approach has pointed out agricultural land and woodland areas as major land uses which have been involved. These areas must be actively managed by farmers because many components of biodiversity would not survive without agriculture. Agri-environmental measures are specifically aimed at supporting agricultural practices to preserve the environment and safeguard the countryside landscape. This favours the participation of farmers without coercion and involves actors to achieve conservation objectives.

Agricultural contributions to enhance biodiversity, soil quality, habitat quality and input reduction favour the achievement of conservation objectives and the improvement of landscape quality.

In this way the multifunctionality of agriculture and the ecological network could be a bridge between rural development programs and environmental conservation plans.

\section{References}

Andersen R., Duncan P., Linnell J.D.C., The european roe deer: the biology of success. 1998, Scandinavian University Press.

Andersen E., Baldock D., Bennett H., Beaufoy G., Bignal E., Brouwer F., Elbersen B., Eiden G., Godeschalk F., Jones G., Mc Cracken D., Nieuwenhuizeb W., Van Eupen M., Hennekens S., Zervas G., Final Report to the EEA on developping a High Nature Value Farming Area Indicator. 2003, Eea Reports.
Adriaensen F., Chardon J.P., De Blust S.G., Swinnen E., Villalba S., Gulinck H. \& Matthysen E., The application of 'least-cost' modelling as a functional landscape model. Landscape and Urban Planning, 2003, 64, 233-247.

Anthony P., Clevenger, J., Wierzchowski, Chruszcz B., Gunson K., GIS-Generated, Expert-Based Models for identifying wildlife habitat linkages and planning mitigation passages. Cons. Biol. 2002, 16 (2), 503-514.

Aulak W., Babinska-Werka J., Use of agricultural habitat by roe deer inhabiting a small forest ara., Acta Theriologica, 1990, 35 (1-2), pp:121-127.

Bani L., Baietto M., Bottoni L., Massa R., The use of focal species in designing a habitat network for a lowland area of lombardy, italy. Cons. Biol. 2002, 16 (3), 826-831.

Beier P., Majka D.R., Spencer W.D., Forks in the road: choices in procedures for designing wildland linkages. Cons. Biol., 2008, 22, No. 4, 836-851.

Bennett G., Integrating biodiversity conservation and sustainable use. Lessons learned from Ecological Networks. 2004. World Conservation Union (Iucn), Gland, Switzerland.

Biemans M., Snethlage M., Country Study for the Netherlands. SPEN - Interactions between Policy Concerning Spatial Planning and Ecological Networks in Europe. 2008 ECNC-European Centre for Nature Conservation.

Boitani L., Falcucci A., Maiorano L., Rondinini C., Ecological Networks as conceptual frameworks or operational tools in conservation. Cons. Biol. 2007, 21 (6), 14141422.

Bonfanti P., Fregonese A., Sigura M., Landscape analysis in areas affected by land consolidation. Landscape and Urban Planning, 1999, 37, 91-98.

Bruinderink G.G., Van Der Sluis T., Lammertsma D., Opdam P., Pouwels R., Designing a coherent ecological network for large mammals in northwestern Europe. Cons. Biol. 2003, 17, (2), 549-557.

Coulon A., Cosson J.F., Angibault J.M., Cargnelutti B., Galan M., Morellet N., Petit E., Aulagnier S. and Hewison A.J.M., Landscape connectivity influences gene flow in a roe deer population inhabiting a fragmented landscape: an individual-based approach. Molecular Ecology, 2004, 13: 2841-2850. doi: 10.1111/j.1365294X.2004.02253.x

Council Regulation (EC) No 1698/2005, 20 September 2005, on support for rural development by the European Agricultural Fund for Rural Development (EAFRD). Official Journal of the European Union L 277/1 21.10.2005.

Council Decision 2006/144/EC, 20 February 2006, on Community strategic guidelines for rural development (programming period 2007 to 2013) Official Journal of the European Union L 55/20, 25.02.2006.

Del Favero R., Dreossi G., Lasen C., Vanone G., Poldini L., Bortoli P.L., La vegetazione forestale e la selvicoltura nella Regione Friuli Venezia Giulia. 1998. Regione Autonoma Friuli Venezia Giulia, Italia.

Doswald N., Zimmermann F., Breitenmoser U., Testing expert groups for a habitat suitability model for the lynx Lynx lynx in the Swiss Alps. Wildl. Biol. 2007,13 430446.

Hewison A.J.M., Vcent J.P., Reby D., Social Organisation Of European Roe Deer, in: The European Roe Deer: the biology of success, Andersen R., Duncan P., Linnell 
J.D.C., Scandinavian University Press, 1998, pp:194219.

Kubeš J., Biocentres and corridors in a cultural landscape. A critical assessment of the territorial system of ecological stability, Landscape and Urban Planning, 1996, 35 (4), 231-240.

Johnston K., Mc Coy J., Spatial Analyst, Using ArcGis, 2001, ESRI.

Jongman R.H.G., Nature conservation planning in Europe: developing ecological networks, Landscape and Urban Planning, 1995, 32 (3) 169-183.

Maulanc M.L., Utilisation de l'espace chez le Chevreuil (Capreolus Capreolus) En Milleieu Ouvert. Gibier Faune Sauvge, 3, 1987, 297-311.

Nikolakaki P., Dunnett N., The use of spatial concepts as a basis for designing a viable-habitat network: conserving redstart (Phoenicurus phoenicurus) populations In Sherwood Forest, England. Journal For Nature Conservation. 2005, 13, 31-48.

Peeters A., Wild and Sown Grasses. Profiles of a temperate species selection: ecology, biodiversity and use. 2004. London: Blackwell Publishing, for FAO. 311 p.

Simonetta A.M., Dessì Fulgheri F., Principi e tecniche di gestione faunistica-venatoria, 2000, Ed Greentime S.P.A.

Schadt S., Knauer F., Kaczensky P., Revilla E., Wiegand T., Trepl L., Rule-based assessment of suitable habitat and patch connectivity for the eurasian lynx. Ecological Applications. 2002, 12(5), 1469-1483.

Saïd S., Servanty S., The influence of landscape structure on female roe deer home-range size, Landscape Ecology. 2005, 20:1003-1012.

Saïd S., Gaillard J.M., Duncan P., Guillon N., Guillon N., Servanty S., Pellerin M., Lefeuvre K., Martin C., Van Laere G., Ecological correlates of home range size in spring-summer for female roe deer in a deciduous woodland. Zool., Lond. 2005, 267, 301-308.

Vuilleumier S., Prélaz-Droux R., Map of ecological networks for landscape planning. Landscape Urban Planning. 2002, 58, 157-170.

World Trade Organization. World Commission On Environment And Development. Our Common Future. Oxford University Press, Oxford.2000. Uk.

Zeida J., Bauerova Z., 1985. Home ranges of field roe deer. Acta Scentiarum Naturalium, Brno. 19 (1), 1987, pp: $1-43$.

\section{SUMMARY}

The concept of multifunctional agriculture refers to the idea that agriculture has many functions in addition to producing food and fiber, like environmental protection, landscape preservation, and rural employment.

The UE Common agricultural policy substains multifunctionality in agriculture by rural development plans that provide relevant frameworks to integrate environmental aims into agriculture.

Integration of environmental instances with socio economical development is an important element also in natural resources conservation strategies. Recently, a new view of the ecological network concept has been developed to produce a more multiobjective vision that defines the ecological network as a system of natural and/or semi-natural landscape elements, that is configured and managed with the objective of maintaining or restoring ecological functions, while also providing opportunities for the sustainable use of natural resources.

The study refers to a method, based on the Geographical Information System (GIS), for assessing the ecological network model in a rural landscape, where human activities are involved. Two models were developed: the landscape model and the connectivity model. The application in the study area showed the capacity of models to identify strategic places for ecological functions. The results pointed out the natural values of the area (matching the protected areas) and the most favourable expected ways of connection, or interruptions, between suitable areas. Agricultural and woodland areas were the main land uses involved in the ecological network structure.

The maps which have been obtained can be useful instruments in order to involve policy makers, and other stakeholders, in the decision process on land use planning. In this way, the ecological network model can be a useful instrument in order to give valuable knowledge about environmental functions of rural landscape and to show constraints and possibilities to change the landscape in the boundaries of sustainability.

Keywords: multifunctional agriculture, ecological network, rural landscape planning, GIS, rural delevopment. 